\title{
CONTRACEPTIVE CHOICE AMONG COUPLES OF CHILDBEARING AGE (PUS) IN BENGKULU PROVINCE
}

\author{
Henni Febriawati ${ }^{1}$, Mario Ekoriano ${ }^{2}$, Wulan Angraini ${ }^{3}$, Edy Purwoko ${ }^{4}$, Iis Suryani ${ }^{5}$ \\ $1,3,5$ Faculty of Health Sciences, Universitas Muhammadiyah Bengkulu, Indonesia \\ ${ }^{2,4}$ Research and Development Center for KB and KS - \\ National Population and Family Planning Commission (BKKBN), Indonesia \\ Corresponding Author: Henni Febriawati \\ Email: henni_febriawati@umb.ac.id
}

\begin{abstract}
Contraceptives are very useful in achieving the family planning (keluarga berencana) program; however, not all contraceptives are suitable for everyone. The choice of contraception depends on how each person must be able to choose a contraceptive that is suitable for him or her. In general, there are two methods of contraception, namely modern and traditional. The government recommends couples of childbearing age or pasangan usia subur (PUS) to use the modern method, as it is more effective in preventing pregnancy. This study was conducted to determine factors (predisposing, enabling, and reinforcing) that influenced the use of contraceptives in Bengkulu Province. The research design was cross-sectional and used secondary data from the Performance Survey and Accountability Program/Survei Kinerja dan Akuntabilitas Program (SKAP) in 2019. The sample of this study was couples of childbearing age ranged 15-49 years old in Bengkulu. The results showed that 232 couples (59.9\%) used modern contraception, while 155 people did not use modern contraception $(40.1 \%)$. The results of the bivariate analysis of predisposing factors show that there is a relationship between work, education, and attitudes towards using family planning in the future, while age and knowledge are not related. It was also found that there are relationships between enabling factors such as place of residence, level of welfare, number of children, desire to have children, and informed choice. Meanwhile, there is no relationship between insurance membership and mass and room information media. It is known that there is no relationship between reinforcing factors in information sources for health workers, non-health workers, information sources for formal institutions, and information sources for nonformal institutions with the selection of contraceptive methods. The factor that most influenced the choice of family planning methods among the respondents aged 15-49 years in Bengkulu was informed choice with OR of $20.11(95 \% \mathrm{CI}=(11.24-35.98)$.
\end{abstract}

Keywords: Family planning, PUS, modern contraception

\begin{abstract}
ABSTRAK
Kontrasepsi sangat bermanfaat dalam pencapaian program keluarga berencana (KB). Namun, dalam keadaannya alat/cara KB bisa digunakan dan sesuai dengan harapan dan kecocokan individu. Pemilihan kontrasepsi tergantung pada bagaimana setiap individu memiliki alasan pribadi untuk menggunakan salah satu kontrasepsi. Secara garis besar, metode kontrasepsi terbagi menjadi dua, yaitu modern dan tradisional. Pemerintah menyarankan pasangan usia subur (PUS) untuk memilih salah satu kontrasepsi modern karena lebih efektif dalam mencegah kehamilan. Penelitian ini bertujuan untuk diketahuinya faktor (predisposing, enabling dan reinforcing) yang mempengaruhi penggunaan alat/cara kontrasepsi pada PUS di Provinsi Bengkulu. Desain penelitian menggunakan pendekatan cross sectional menggunakan data sekunder dari Survei Kinerja dan Akuntabilitas Program (SKAP) keluarga tahun 2019. Sampel penelitian cakupan wilayah Provinsi Bengkulu pada umur 15-49 tahun sebanyak 387. Penelitian ini menggunakan analisis univariabel, bivariabel kai kuadrat, dan multivariabel regresi logitik berganda. Penelitian menunjukkan 232 orang (59,9\%) memilih kontrasepsi modern dan sebanyak 155 orang $(40,1 \%)$ tidak memilih salah satu kontrasepsimodern. Hasil analisis bivariat dari faktor predisposing menunjukkan ada hubungan pekerjaan, pendidikan dan sikap penggunaan KB di masa yang akan datang, sedangkan umur dan pengetahuan tidak berhubungan, dari faktor enabling diketahui bahwa tempat tinggal, tingkat kesejahteraan, jumlah anak, keinginan memiliki anak, dan informed choice berhubungan, sedangkan kepesertaan asuransi, media massa dan media informasi ruangan tidak berhubungan. Tidak terdapat hubungan faktor penguat (sumber informasi petugas kesehatan, petugas non kesehatan, sumber informasi institusi formal, dan sumber informasi institusi non formal) dengan pemilihan metode kontrasepsi. Faktor yang paling berpengaruh terhadap pemilihan kontrasepsi pada responden usia 15-49 tahun di Provinsi Bengkulu adalah pilihan berdasarkan tujuan dengan OR 20,11 (95\% CI = (11,24-35,98).
\end{abstract}

Kata Kunci: Keluarga berencana, PUS, kontrasepsi modern 


\section{INTRODUCTION}

Family planning tools/methods are useful for family planning programs, however, different individuals suit different family planning tools/methods. When making the decision to choose a family planning tool/method, each individual should think about whether the family planning tool/method is suitable for use by him/herself (Bengkulu Provincial Health Office, 2019) because they have different strengths and weaknesses depending on the individual. The selection of family planning tools/methods is also closely related to the available family planning services. Therefore, quality family planning services contribute to contraceptive acceptance and user satisfaction.

Bruce (1990) stated that quality of service includes six elements, the ability to choose family planning tools/methods, information obtained regarding the choice of family planning tools/methods to users/acceptors, staff expertise in providing family planning tools/methods, interpersonal relationships, technical systems to support improvement continued service and suitability of service providers from officers. The Indonesian Demographics Health Survey (IDHS) (2017) data shows that injections and oral contraception are modern family planning tools/methods and periodic abstinence methods are widely known by women in Indonesia. Whereas condoms and oral contraception are modern family planning tools/methods and interrupted intercourse methods (traditional family planning tools/methods) are best known by men in Indonesia. On average, women have a higher understanding of one type of contraceptive method than men. In the future, more women will choose/use one method of family planning than men. According to IDHS data, the age range of 15-24 years is also a group that knows a lot about modern family planning tools/methods ( $94 \%$ women and $79 \%$ men). Moreover, the percentage of individuals who know about family planning tools/methods is $96 \%$ for women and 93 for men (IDHS, 2017).

Meanwhile, the Family Information System - National Population and Family Planning Commission (Sistem Informasi Keluarga - Badan Kependudukan dan Keluarga Berencana Nasional) data (2019) shows that in Bengkulu Province, 8,260 people chose to use one of the long-term family planning methods, which consists of 1,700 people using implants, 352 people using IUDs, 139 people using tubectomy or MOW (metode operasi wanita), and 38 people using vasectomy or MOP (metode operasi pria). Whereas the total number of people using non-long-term family planning devices/methods is 2,229 people, which consists of 6,897 people using contraceptive injections, 1,149 people using birth control pills, and 214 people using condoms.

The methods and intentions in making the decision to use family planning tools/methods will be directly proportional to knowledge about family planning tools/methods and attitudes possessed by a person (Zuraidah, 2017). Urban married women have better/higher knowledge than married women in rural areas, but it is inversely proportional to the percentage of married women in rural areas who choose one of the modern methods of family planning $(62 \%)$ and urban married women (55\%). Education is also inversely proportional to the woman's level of education and the level of selection in the use of one method of family planning. Age level affects the choice of family planning tools/methods, both modern and traditional, the higher a person's age will be inversely proportional to the decrease in the use of family planning tools/methods. Sources of information are a factor that has a role in the selection/use of family planning tools/methods for a married woman (Syamsul, Bakri and Limonu, 2020).

Many studies have investigated the relationship and influence of factors regarding the choice of contraceptive methods, but there are still few that group these factors through theory. Green and Kreuter (2005) stated that predisposing, enabling, and reinforcing factors are the most important factors in influencing a person's behavior, including decision making in the selection of family planning tools/methods. This is the novelty in this study.

This study determined the predisposing factors (age, occupation, knowledge, education, attitudes towards the use of family planning tools/methods and decisions to use family planning tools/methods in the future), enabling factors (insurance participation, place of residence, welfare level, number of children, desire to use family planning, mass information media, space information media, family planning needs, informed choice, family 
planning services, cost of services for family planning tools/methods covered by insurance and places of service), reinforcing factors (sources of information from health workers, sources of information from non-health workers, sources of information from formal institutions, and sources of information from non-formal institutions) that influence and is the most dominant factor in influencing the type of decision to use family planning tools/methods for couples of childbearing age / pasangan usia subur (PUS) in Bengkulu Province.

\section{METHOD}

The research design applied is a crosssectional study that uses secondary data from the Bengkulu Province Population, Family Planning and Family Development Performance Survey and Accountability Program in 2019, with their Family Module that used the Women of Childbearing Age questionnaire. The study used the variable selection of family planning tools/methods in PUS with the definition of using one type of modern family planning tool/method and not using modern family planning tools/methods at all. The determination of the population and sample size in this further analysis refers to the 2019 Family Planning and Family Development Performance Survey and Accountability Program data. The research sample are couples of childbearing age who are 15-49 years of age in 10 districts/cities in Bengkulu Province. Based on the Family Planning and Family Development Performance Survey and Accountability Program 2019 data, the number of couples of childbearing age samples in Bengkulu is as many as 387 . The study used univariate data analysis, bivariate Chi-square, and multivariate analysis with multiple logistic regression.

\section{RESULTS}

Based on the results of the univariate analysis in Figure 1, it was found that for couples of childbearing age of 15-49 years in Bengkulu Province, 59.9\% use modern family planning tools/methods and $40.1 \%$ do not use modern family planning methods/methods

The results of the bivariate ChiSquare analysis of the factors associated with the selection of the use of family planning tools/methods in couples of childbearing age that are aged 15-49 years in Bengkulu Province can be seen in Table 1. The predisposing factor and related variables are the occupation $\mathrm{p}=0.001$ ), education $\mathrm{p}=0.003$ ), family planning decisions $\mathrm{p}=0.000$ ), and attitudes towards future use of family planning $p=0.000$ ). Meanwhile, there is no relationship between age $p=1.000$ ) and knowledge $(\mathrm{p}=1.000)$.

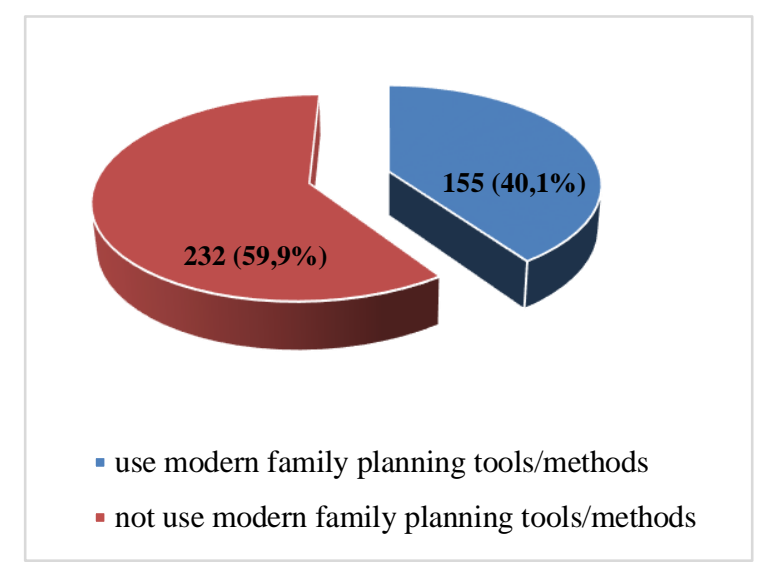

Figure 1. Distribution of the Use of Family Planning Tools/Methods in Bengkulu Province

The related enabling factors are the place of residence $p=0.000$ ), level of welfare $\mathrm{p}=0.003$ ), number of children $\mathrm{p}=0.013$ ), desire to have children $p=0.001$ ), and informed choice $\mathrm{p}=0.000$ ). The results also showed no relationship for insurance membership $\mathrm{p}=0.099$ ), mass information media $\mathrm{p}=0.089$ ), and room information media $\mathrm{p}=0.962$ ). Meanwhile, for reinforcing factors, there was no correlation for sources of information on health workers $\mathrm{p}=0.231$ ), information sources for non-health workers $\mathrm{p}=0.669$ ), sources of information on formal institutions $\mathrm{p}=0.507$ ), and sources of information on non-formal institutions $\mathrm{p}=0.985$ ).

After the bivariate analysis was performed, the analysis was continued with multivariates by using logistic regression. Table 2 shows that the three variables that most influence the choice of modern family planning tools/methods are occupation, place of residence, and informed choice. Moreover, couples of childbearing age who work are 1.87 times more likely to use one of the modern family planning tools/methods as compared to couples of childbearing age who do not work (95\% CI $=1.09-3.21)$; couples of childbearing age who live in urban areas are 0.335 times more likely to use one of the tools/ modern family planning methods as compared to 
mothers who live in rural areas $(95 \% \mathrm{CI}=$ 0.187-0.598), and couples of childbearing age who get an informed choice are 20.11 times more likely to use one of the modern family planning tools/methods as compared to couples of childbearing age who do not get an informed choice.

Based on these three factors, the most dominant factor in influencing the choice of the use of modern family planning tools/methods is informed choice. Women who received information related to side effects/problems that may arise in the use of one of the contraceptive methods, and are informed of the actions to be taken if side effects/problems arise in the use of family planning tools/methods, and were informed about other family planning tools/methods are 20.11 times more likely to use one of the modern family tools/methods compared to women who do not get the three informed choice information (provided information related to side effects/problems that may arise, actions to be taken if there are problems, and informed of other family planning tools/methods) $(95 \% \mathrm{CI}=11.24$ 35.98).

\section{DISCUSSION}

Green and Kreuter (2005) stated that two factors affect individual or community health, one of which is health behavior factors. The three main factors that influence a person's health behavior includes decision making in the selection of family planning tools/methods at PUS, namely: predisposing, enabling, and reinforcing factors.

\section{Use of Family Planning Tools/Methods in Bengkulu Province}

For rouples of childbearing age that are 15-49 years in Bengkulu Province, there is as many as 387 couples of childbearing age, of which 155 people or $40.1 \%$ of couples who do not use modern family planning tools/methods. Some couples use traditional methods of contraception. The reasons why these couples do not access family planning services was studied by Apanga and Adam (2015) and they found that for $90 \%(207 / 230)$ of the families in the study it was a challenge for husbands to access family planning services and $83 \%$ (191/230) of the couples had misconceptions about family planning. Although most women know about family planning services in Talensi
District, the uptake of these services is still low. Thus, the District Health Office must intensify health education about the benefits of family planning and involve the men too. The government should also improve family planning services in districts to make them more accessible.

Table 2. Use of Family Planning Tools/Methods for Couples of Childbearing Age (15-49 years) in 2019 in Bengkulu Province

\begin{tabular}{lcccc}
\hline Variable & B & OR & P-value & $\begin{array}{c}\text { OR } \\
(\mathbf{9 5 \%} \\
\text { CI })\end{array}$ \\
\hline Work & & & & \\
\hline $\begin{array}{l}\text { Does not } \\
\text { work }\end{array}$ & & & & \\
$\begin{array}{l}\text { Work } \\
\text { Onformed Choice }\end{array}$ & & & \\
\hline Not & & & & \\
Notified & & & & \\
Notified & 3,002 & 20.11 & 0.00 & $(11.24-$ \\
& & & & $35.98)$ \\
\hline Residence & & & & \\
\hline village & & & & \\
City & 0.335 & 0.000 & $(0.187-$ \\
& 1.094 & & & $0.598)$ \\
\hline
\end{tabular}

Source: Secondary data on Family Planning and Family Development Performance Survey and Accountability Program of Women of Childbearing Age, Family Information System National Population and Family Planning Commission Bengkulu Province, in 2019 processed by researchers

\section{Predisposing Factors}

The predisposing factors studied were age, occupation, education, knowledge, attitudes towards using family planning in the future. The results of the analysis of bivariable processing in Table 1 showed that there is a relationship between employment, education, decisions to use family planning, and attitudes to future family planning with the use of modern family planning tools/methods. However, age and knowledge are not related.

\section{Work}

The results showed that couples of childbearing age who work will be more likely to use one of the modern family 
planning tools/methods compared to those who do not work. A working mother will appreciate effectiveness and efficiency by using contraception because of their busy lives. In a similar study, Ningrum, Easter, and Sugihati (2018) obtained a p-value of 0.009 for the relationship between use of contraception and work, which suggests that there is a relationship between the two. Couples who work, of course, both have busy lives and also extensive relationships, so they decide to use modern family planning tools/methods that can provide a sense of security and eliminate anxiety about getting pregnant again.

\section{Education}

The bivariate analysis for the education factor found that education was related to the use of the choice of contraceptive methods for couples of childbearing age between 15 - 49 years old in Bengkulu Province. Education is the most effective factor from other factors related to the use of family planning devices at Tabang Village and Bolong Village in North Walenrang District ( $p$ $=0.01)$ (Ramli and Muhli, 2019). This research is also in line with Kurniawan (2019) which stated that a woman who has a higher education will obtain more information, especially related to family planning and reproductive health so she can choose the means of family planning used.

\section{Attitudes for Use of Family Planning In The Future}

As many as $64.7 \%$ of women in Bhubaneswar have used contraception in the past and $24.26 \%$ have never used contraception before, but they think that family planning is beneficial, so they are still willing to use family planning in the future. This is in line with the research of Jena et al., (2017), who feel the benefits of using modern family planning, on the results of the analysis of this study. The selection of modern family planning tools/methods for women aged 15-49 years old in Bengkulu Province is related to attitudes towards future family planning use. The attitude of couples of childbearing age who will use family planning in the future will greatly support the government's program in reducing Indonesia's population density.
Age

Couples of childbearing age between 1549 years old are the government's target group for family planning programs because this group consists of women who have a great opportunity to get pregnant and give birth to many children. A study conducted by Huda, Widagdo, and Widjanarko (2016) showed that there was no relationship between age and contraceptive use behavior $\mathrm{p}=0.282$ ). The analysis shows that there is a lack of behavior in the use of contraception in the high-risk age group (47.2\%). As for the low-risk age group, the result is $33.9 \%$. The period when the reproductive organs are ready and mature enough to contain a fetus (pregnancy) and give birth to children is for women aged between 20-35 years. This is the best age for a woman to get pregnant. While women who are at the age of >35 years have a high risk of complications when pregnant and giving birth to children. Therefore, to prevent high risk pregnancies, the use of contraception is necessary.

This study showed that age is not related to the use of modern family planning tools/methods in couples of childbearing age between 15 - 49 years old in Bengkulu Province. This result is in line with research conducted by Aminatussyadiah and Prastyoningsih (2019) which stated that there is no relationship between age and the choice of contraception in women of childbearing age with a p-value of 0.303 . This is because age does not always reflect the maturity of a person to want to obtain and absorb information. Conversely, Kurniawan et al., (2019) stated that there is a relationship between age and the use of family planning tools/methods in East Java. The study shows that women aged 35-39 years have the highest proportion of using family planning methods/methods.

\section{Knowledge}

The results showed that there was no relationship between knowledge and the use of modern family planning methods for couples of childbearing age. According to Ahmad, Hutagaol, and Malara (2014), there is no significant relationship between the knowledge of adolescent and young adult mothers about family planning and the use of contraceptives at 
Table 1. Factors related to the selection of family planning tools/methods at couples of childbearing age that are 15-49 years old in Bengkulu Province in 2019

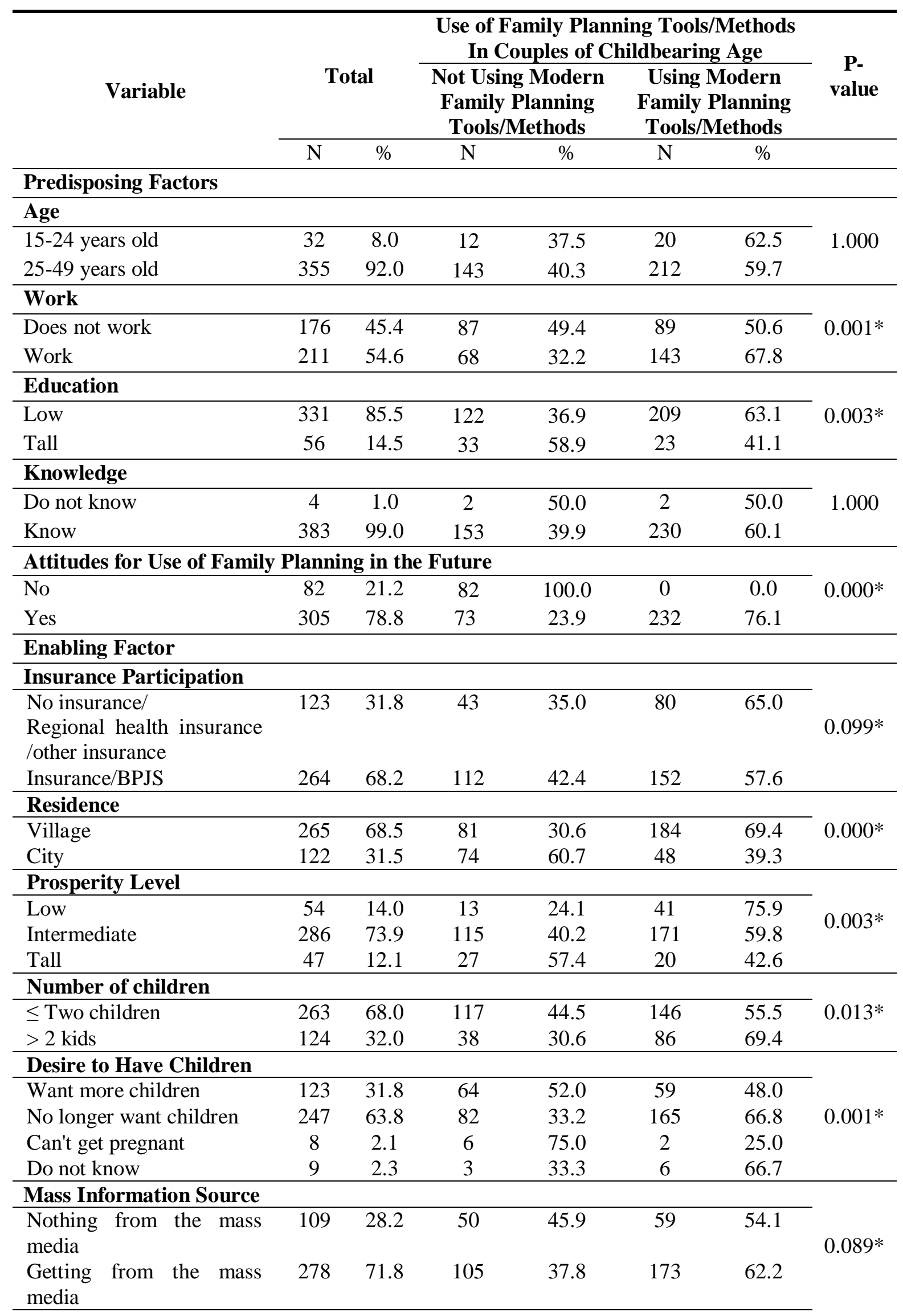




\begin{tabular}{|c|c|c|c|c|c|c|c|}
\hline \multirow{3}{*}{ Variable } & & & \multicolumn{4}{|c|}{$\begin{array}{l}\text { Use of Family Planning Tools/Methods } \\
\text { In Couples of Childbearing Age }\end{array}$} & \multirow{3}{*}{$\begin{array}{c}\text { P- } \\
\text { value }\end{array}$} \\
\hline & \multicolumn{2}{|c|}{ Total } & \multicolumn{2}{|c|}{$\begin{array}{c}\text { Not Using Modern } \\
\text { Family Planning } \\
\text { Tools/Methods }\end{array}$} & \multicolumn{2}{|c|}{$\begin{array}{l}\text { Using Modern } \\
\text { Family Planning } \\
\text { Tools/Methods }\end{array}$} & \\
\hline & $\mathrm{N}$ & $\%$ & $\mathrm{~N}$ & $\%$ & $\mathrm{~N}$ & $\%$ & \\
\hline \multicolumn{7}{|l|}{ Space Information Media } & \multirow{3}{*}{0.962} \\
\hline Nothing from space media & 10 & 2.6 & 5 & 50.0 & 5 & 50.0 & \\
\hline It is from space media & 377 & 97.4 & 151 & 40 & 226 & 60 & \\
\hline \multicolumn{7}{|l|}{ Informed Choice } & \multirow{3}{*}{$0.000^{*}$} \\
\hline $\begin{array}{l}\text { Not given any informed } \\
\text { choice }\end{array}$ & 194 & 50.1 & 135 & 69.6 & 59 & 30.4 & \\
\hline Given one informed choice & 193 & 49.9 & 20 & 10.4 & 173 & 89.6 & \\
\hline \multicolumn{8}{|l|}{ Reinforcing Factor } \\
\hline \multicolumn{7}{|c|}{ Health Officer Information Source } & \multirow{3}{*}{0.231} \\
\hline None from health workers & 89 & 23.0 & 41 & 46.1 & 48 & 53.9 & \\
\hline There are health workers & 298 & 61.7 & 114 & 38.3 & 184 & 61.7 & \\
\hline \multicolumn{7}{|c|}{ Source of Information for Non-Health Officers } & \multirow{3}{*}{0.669} \\
\hline $\begin{array}{l}\text { None from non-health } \\
\text { workers }\end{array}$ & 22 & 5.6 & 7 & 32.0 & 15 & 68.0 & \\
\hline $\begin{array}{l}\text { There are non-health } \\
\text { workers }\end{array}$ & 365 & 94.4 & 148 & 40.5 & 217 & 59.5 & \\
\hline \multicolumn{7}{|c|}{ Sources of Information from Formal Institutions } & \multirow{3}{*}{0.507} \\
\hline $\begin{array}{l}\text { Not getting from formal } \\
\text { education }\end{array}$ & 317 & 81.9 & 124 & 39.1 & 193 & 60.9 & \\
\hline Getting from formal & 70 & 18.1 & 31 & 44.3 & 39 & 55.7 & \\
\hline \multicolumn{7}{|c|}{ Sources of Information from Non-Formal Institutions } & \multirow{4}{*}{0.985} \\
\hline $\begin{array}{l}\text { None from non-formal } \\
\text { education }\end{array}$ & 66 & 17.1 & 27 & 40.9 & 39 & 59.1 & \\
\hline $\begin{array}{l}\text { Some are from non- } \\
\text { formal } \\
\text { education/community } \\
\text { organization/toga }\end{array}$ & 321 & 82.9 & 128 & 39.9 & 193 & 60.1 & \\
\hline $\begin{array}{l}\text { Information: } \\
\text { *Significance } 10 \%\end{array}$ & & & & & & & \\
\hline
\end{tabular}

Source: Secondary data from the Family Planning and Family Development Performance Survey and Accountability Program of Women of Childbearing Age, Family Information System - National Population and Family Planning Commission Bengkulu Province, in 2019 processed by the researchers

the Mabapura Health Center, East Halmahera Regency. People still hold their customs and religion tightly. They believe that the more children they have, the more sustenance they will get, therefore many of them continue to have more children and neglect the use of contraceptive methods.

According to the researcher, the knowledge obtained by couples of childbearing age must be knowledge that passes through the stages of awareness, interest, evaluation, trial, and adoption. This is so that the resulting behavior will last a long time. If the behavior results or changes from the knowledge gained continues, then another couple of childbearing age will spread their knowledge and experience with others. This research is limited because the definition of knowledge from the Family Planning and Family Development Performance Survey and Accountability Program data is from the composite of questions on whether the respondent has heard/seen/read the types of contraception devices/methods (tubectomy, vasectomy, implant, IUD/spiral, IUD, Injectable contraceptive, contraceptive pills, emergency contraception, condoms, condoms for women, intravag/diaphragm, standard day method/bead bracelet, lactational 
amenorrhea method, periodic/calendar abstinence method, and interrupted intercourse method.

The knowledge is sometimes in line with a person's attitude or behavior, but in this study, there is no relationship between knowledge and the choice of family planning tools/methods. It is possible that couples of childbearing age already have good knowledge but there is encouragement/support/desire from within to want to add children even though sometimes they already have a pair of children. There is also the possibility that there is still an assumption that using family planning tools/methods is rejecting sustenance from God.

\section{Enabling Factor}

Nugroho et al. (2019) assessed the availability of contraception, human resources, the flow of referrals, and information provided by health officers as enabling factors and based on the statistical analysis conducted, no significant relationship was found with all of the enabling factors with the use of modern contraception. Other research conducted by Rosalina (2019) stated that the enabling factor that allows a mother to use birth control methods is affordable family planning costs and access to services in good family planning programs.

In this study, the enabling factors used by the researcher are residence, level of welfare, number of children, desire to have children, informed choice, insurance participation, mass information media, and room information media. The results of the analysis showed that residence, level of welfare, number of children, desire to have children, and informed choice is related to the selection of family planning tools/methods for women aged 15-49 years. Meanwhile, insurance participation, mass information media, and room information media are not related.

\section{Residence}

There is a relationship between the place of residence of couples of childbearing age between 15 - 49 years old in the village and the city with the choice of modern family planning tools/methods in Bengkulu Province. This result is in line with the analysis conducted by Aminatussyadiah and Prastyoningsih (2019) who found that there is a relationship between residence and the choice of contraception for women of childbearing age $p=0.000$ ). For women whose status of residence are in urban areas, out of 5,396 respondents, 2,453 respondents chose to use the contraceptive pill, 2,078 used an IUD, 922 used implants, and 873 respondents chose to use contraceptive injections. Meanwhile, for women who live in rural areas, out of 3340 respondents, 1,646 respondents chose to use the contraceptive pill, 749 used implants, 539 used full family planning and 406 respondents chose to use the IUD.

To achieve universal coverage, it should not only be the number of residents who are registered in the Social Security Agency for Health(Badan Penyelenggara Jaminan Sosial Kesehatan) that are counted, but the fulfillment of the ratio of health service facilities is calculated. The location of population settlements that are scattered and are in geographically challenging areas is a natural condition that cannot be changed that demands the fulfillment of health service facilities (Yandrizal et al., 2016). Primary service programs such as the use of family planning tools/methods that aim at the community to improve health in Bengkulu Province, in particular, must be successful in narrowing and even eliminating the gap between rural and urban communities in obtaining health services.

\section{Prosperity Level}

There is a relationship between the level of welfare and the choice of family planning tools/methods for women aged 15-49 years. The level of family welfare is measured by its wealth index. According to Siahaan, Santosa, and Sanusi (2020) shows that the average use of long-term family planning methods at the age of $>35$ years is influenced by the highest wealth index. Moreover, Syamsul, Bakri, and Limonu (2020) concluded that the proportion of women in the lowest wealth quintile who use modern family planning methods is higher than the proportion of women use modern family planning methods in the top wealth quintile. The highest proportion of the use of traditional family planning tools/methods is found in women with the highest wealth quintile. There is also a high proportion of working women with a large number of children compared to women with a few children. Megawati's research in 2015 also concluded that there is a relationship between 
economic status and the choice of contraceptives. The selection of the best means/method is seen from the capacity of a person's ability to buy the contraceptive tool/method. The selection of family planning tools/methods to be used tends to be less burdensome for the wearer for women without work or those who work.

\section{Number of Children}

This study found that there is a relationship between the number of children and the choice of modern family planning tools/methods. Couples of childbearing age with more than 2 children prefer to use modern family planning methods/tools compared to couples of childbearing age with 2 children (Table 1). This is in line with the results of the analysis Dewiyanti (2020) conducted where the factor of contraceptive use is influenced by the number of children with a $\mathrm{p}$-value $=0.074$. Couples who have had a large number of children tend to use contraception with a higher level of effectiveness, while couples with a small number of children tend to use contraceptive methods with a low level of effectiveness.

Factors that influence the choice of contraceptives used by women are related to the number of living children. Women who have less than 2 living children will be 20.51 times more likely to use hormonal contraception (implants, injections, and pills) than women who have more than 2 children. This is less effective because if a woman forgets to use contraception regularly and periodically it will affect the program from regulating pregnancy spacing and improving family welfare (Ramania, 2020).

Users of contraceptive implants and IUDs are more in demand by women who have fewer children ( $0-2$ people). However, different things were found in contraception that is permanent in demand by women who have had more than two children (Ekoriano and Novita 2018).

The biggest motivation for a woman to use one of the methods of family planning is the number of living children they have. Thus, if women are satisfied with their number of children, the motivation to use one of the modern/traditional family planning tools/methods will be greater. This is supported by the age of women 35-39 years who are approaching menopause, as they are more likely to feel like they have had enough children and will choose one method of family planning (Kurniawan et al., 2019).

\section{Desire to Have Children}

The results of the analysis showed that the desire to have children is related to the choice of the type of use of modern family planning tools/methods for couples of childbearing age between 15 - 49 years in Bengkulu Province. According to Handayani and Najib (2019), the desire to have children is influenced by the number of children the family has, the perception of the ideal number of children, socioeconomic status, location of residence, and level of education. Families with high incomes tend to prioritize the quality of children over quantity. This is because parents want to be able to provide the best education for their children.

This is in line with the analysis conducted by Sumartini and Indriani (2017), they found that there is a relationship between the desire to have children and the use of contraception in couples of childbearing age. Families who do not have children or have just had one child still have a great desire to add new family members. How many children a family wants depends on the family's agreement. Some families want one, two, or three children and so on depending on their ability. The decision to have another child is a choice. These choices are influenced by values that are considered very important by a family. This desire to add or not have more children affects the use of family planning methods used.

\section{Informed Choice}

The application of informed choice in contraceptive services is an effort to improve the quality of services and the coverage of family planning. Informed choice is defined as a process of delivering complete information to participants as prospective family planning users through counseling so that they have the knowledge to choose certain contraceptives that are best for them. Research conducted by Donsu, Purnama, and Tjondrorini (2013) showed that the motivation with the performance of village midwives in the application of informed choice in contraceptive services is closely related.

Mothers who receive information regarding side effects that may arise in the use 
of one method of family planning are informed of the actions to be taken if these side effects arise and are informed about other family planning options are 20.11 times more likely to use one of the modern family tools/methods as compared to mothers who do not get any of the informed choice information.

The informed choice regarding the use of long-term contraceptives from health workers is best given from the start of the pregnancy program. This is proven by research conducted by DeSisto et al., (2018) where 34 respondents received an informed choice and more than $90 \%$ of the respondents decided to use long-term contraceptives immediately after delivery (24 implants, 1 IUD). The majority of women believe the right time to use contraception in the hospital is immediately after giving birth, although $40 \%$ of respondents want the contraception to be put out again.

\section{Insurance Participation}

A total of 264 couples of childbearing age who are Social Security Agency for Health insurance participants, as many as 152 of them $(57.6 \%)$ used modern family planning tools/methods, and of the 123 couples of childbearing age who did not become insurance participants, 80 of them $(65.0 \%)$ used modern family planning tools/methods. The bivariable analysis of this study found that there was no relationship between insurance participation and the choice of the type of use of modern family planning tools/methods in women aged 15-49 years.

The research conducted by Sari, Abidin, and Ningsih (2019) shows results that are in line with the analysis of this study, and there is no relationship between Social Security Agency for Health ownership in the choice of contraception, with a p-value of 0.132. Many people think that Social Security Administrator for Health cards can only be used for treatment, so the use of these insurance cards by women or couples to get family planning services is still very low.

This study contradicts the results obtained by Oesman (2017). The results show that participants who use the Social Security Agency for Health card have the opportunity to use the long-term family planning method by 3.8 times higher compared to those who do not use the BPJS health card. The results obtained a p-value of $<0.005$, so it can be concluded that there is a difference in the proportion of the use of Social Security Agency for Health cards to the family planning method (long-term contraceptive and short-term contraceptive) used with a significant relationship $(\mathrm{p}=0.001$; $\mathrm{OR}=3.814$ ).

\section{Mass Information Media and Room Information Media}

The use of media is one of the strategies in disseminating information and education about family planning programs in the community. Meanwhile, the right type of media to convey information will help a person to determine the choice of a method or contraceptive that suits his or her needs. The results showed that mass information media and room information media were not related to the selection of modern family planning tools/methods among women aged 15-49 years in Bengkulu Province. People still think that information obtained through mass and room media only shows the positivity without adding the negative one, so they have the belief that it cannot be proven. This research is in line with Santikasari and Laksmini (2019) who concluded that there was no influence of television media with the use of family planning tools/methods because couples of childbearing age watched soap operas more often. There was also a lack of information about the working mechanism, advantages, and disadvantages of family planning to be used. Therefore, contraceptive advertisements or family planning should be shown on TV to increase the awareness of family planning.

\section{Reinforcing Factor}

There is no single reinforcing factor that is related (sources of information on health workers, non-health workers, sources of information on formal institutions, and sources of information on non-formal institutions) in this study with the selection of modern family planning tools/methods in couples of childbearing age between 15-49 years old in Bengkulu Province. From the client's point of view, information on contraceptive options is the most neglected aspect in public health facilities. Emphasis should be given to shaping the behavior of health care providers. The concept of quality objectives needs to pay attention to the maturity of cross-regional programs. Periodic monitoring and evaluation 
are needed to better ensure client satisfaction and lead to a more sustainable use of modern contraceptives (Ekoriano and Irma, 2018).

Wagner et al. (2018) said that knowledge and valid sources of information can be a factor driving the intensity of contraceptive use. Some $97 \%$ of respondents heard about contraception from at least one source and $49 \%$ of them used contraception when needed. The results of this study found that there is a relationship between knowledge and credibility of sources of information on the intensity of the decision to use contraception.

The activities conducted by the Healthy Family Approach Program in Indonesia in primary health care facilities or community health centers has increased. These activities includes planning, collecting data between programs, across programs, going down to the communities, creating maps, conducting home visits with teams going to the field regularly, holding problem interventions, and having continuous evaluation by evaluating changes in community behavior or the Healthy Family Index (Febriawati et al., 2020).

\section{CONCLUSION AND SUGGESTIONS}

\section{Conclusion}

For couples of childbearing age between 15-9 years old in Bengkulu Province, as many as 232 people (59.9\%) used modern family planning tools/methods and 155 people (40.1\%) did not use modern family planning methods/methods. The most dominant factor in influencing the selection of the use of family planning tools/methods is the enabling factor, namely informed choice $(95 \% \mathrm{CI}=11.24$ 35.98).

\section{Suggestion}

It is recommended to increase family planning cadres in providing information related to the types of family planning tools/methods, the weaknesses and strengths of family planning tools/methods, and information related to the selection of family planning tools/methods. This information is shared to prospective mothers and could be given to prospective brides, as well as to mothers who are married in the form of counseling on family planning. The results of this study are expected to be used as input for policy making and family planning programs.

\section{REFERENCES}

Ahmad, S., Hutagaol, E. dan Malara, R., 2014. Hubungan Pengetahuan Ibu Usia Remaja dan Dewasa Muda tentang KB Dengan Penggunaan Alat Kontrasepsi Setelah Melahirkan di Puskesmas Mabapura Kabupaten Halmahera Timur. E-Journal Universitas Sam Ratulangi, 2(2) pp.1-7.

Aminatussyadiah, A. dan Prastyoningsih, A., 2019. Faktor Yang Mempengaruhi Penggunaan Kontrasepsi Pada Wanita Usia Subur di Indonesia (Analisis Data Survei Demografi dan Kesehatan Indonesia Tahun 2017 ). Journal of Chemical Information and Modeling, 53(9), pp.1689-1699.

Apanga, P.A. dan Adam, M.A., 2015. Factors Influencing The Uptake of Family Planning Services In The Talensi District, Ghana. Pan African Medical Journal, 20, pp.1-9.

Bengkulu Provincial Health Office, 2019. Profil Kesehatan Provinsi Bengkulu Tahun 2018. Bengkulu Provincial Health Office.

Bruce, J., 1990. Fundamental Elements of The Quality of Care: a Simple Framework. Studies in Family Planning, 21(2), pp.61-91.

DeSisto, C.L., et al., 2018. Women's Informed Choice and Satisfaction With Immediate Postpartum Long-Acting Reversible Contraception in Georgia. Contraception and Reproductive Medicine, 3(1), pp.1-10.

Dewiyanti, N., 2020. Hubungan Umur Dan Jumlah Anak Terhadap Penggunaan Metode Kontrasepsi di Puskesmas Bulak Banteng Surabaya. Medical Technology and Public Health Journal, 4(1), pp.70-78.

Donsu, A., Purnama, C.T. dan Tjondrorini, 2013. Faktor-faktor yang Berhubungan dengan Kinerja Bidan Desa dalam Penerapan Informed Choice dan Informed Consent pada Pelayanan Kontrasepsi di Kabupaten Minahasa Utara. Jurnal Manajemen Kesehatan Indonesia, 1(02), pp.143-152. 
Ekoriano, M. dan Irma, A., 2018. Quality of Care in Modern Contraceptive Service Delivery in the Public and Private Sector: A Cross Sectional Study in Indonesia. Global Journal of Health Science, 13(1), pp.27-38.

Ekoriano, M. dan Novita, F., 2018. Dinamika Pemakaian Kontrasepsi Modern di Indonesia (Analisis Data Susenas 2015) the Dynamic of Modern Contraceptive Use in Indonesia (Analysis of Susenas 2015 Data). Jurnal Kependudukan Indonesia |, 13(Juni), pp.27-38.

Febriawati, H., Angraini, W., Lina, L.F., Oktarianita, O. dan Pratiwi, B., 2020. Analysis of Indonesian Health Program Through Family Approcah (PIS-PK) in the Working Area of Public Health Center of Jalan Gedang. Pakistan Journal of Medical and Helth Science. Pakistan, 14(1), pp.581-585.

Green, L.W. dan Kreuter, M.W., 2005. Health Program Planning: An Educational and Ecological Approach. Fourt Edition. Newyork: McGraw-Hill.

Handayani, A. dan Najib, N., 2019. Keinginan Memiliki Anak Berdasarkan Teori Pilihan Rasional (Analisis Data Sdki Tahun 2017). EMPATI-Jurnal Bimbingan dan Konseling, 6(2), pp.3140.

Huda, A., Widagdo, L. dan Widjanarko, B., 2016. Faktor-Faktor yang Berhubungan dengan Perilaku Penggunaan Alat Kontrasepsi Pada Wanita Usia Subur di Puskesmas Jombang-Kota Tangerang Selatan. Jurnal Kesehatan Masyarakat (e-Journal), 4(1), pp.461-469.

IDHS, 2017. Survei Demografi dan Kesehatan Indonesia 2017: Buku Remaja. National Population and Family Planning Commission. [online] Available at: <http://www.dhsprogram.com. >.

Jena, S., et al., 2017. Awareness , Attitude , Practice and Future Use of Family Planning Methods in Bhubaneswar, Odisha. IOSR Journal Of Humanities And Social Science (IOSR-JHSS), 22(9), pp.57-63.

Kurniawan, A., Herowati, D., Kuntoro dan Wibowo, A., 2019. Factors Influencing Contraceptive Use Among Reproductive-Age Women In East Java, Indonesia. Indian Journal of
Public Health Research and Development, 10(9), pp.1359-1363.

Ningrum, D.A.W., Easter, Y.D. dan Sugihati, 2018. Faktor-Faktor yang Berhubungan dengan Pemilihan Metode Kontrasepsi Jangka Panjang (MKJP) Pada Pasangan Usia Subur di Wilayah Kerja Puskesmas Batang Hari Kabupaten Lampung Timur. Jurnal Dunia Kesmas, 7(4), pp.652-656.

Nugroho, A.S., Azhari, A., Nurtjahyo, A. dkk., 2019. Factors Associated with Reproductive Age Couples' Selection of Sterilization in the Era of the National Health Insurance Program. Indonesian Journal of Obstetrics and Gynecology, 7(2), pp.110-115.

Oesman, H., 2017. Pola Pemakaian Kontrasepsi dan Pemanfaatan Kartu Badan Penyelengara Jaminan Sosial Kesehatan Dalam. Jurnal Kesehatan Reproduksi, 8(1), pp.15-29.

Ramania, N.A.C., 2020. Determining Factors Related To the Type of Contraceptives in Indonesia. Jurnal Biometrika dan Kependudukan, 9(2), pp.112.

Ramli, H.W. dan Muhli, S.O., 2019. Factors Associated with the Selection of Contraception Devices in Fertile Age Couples in Tabang Village Bolong Village North Walenrang Districh Luwu Regency in 2016. Journal of Health Science and Prevention, 3(3S), pp.57-62.

Rosalina, S., 2019. Gambaran Faktor Predisposing, Enabling Dan Reinforcing $\mathrm{Kb}$ Vasektomi. Jurnal PROMKES, 7(1), pp.113.

Santikasari, S. dan Laksmini, P., 2019. Hubungan Sumber Informasi dengan Pemakaian Kontrasepsi di Kelurahan Merak Tangerang. Jurnal Ilmu Kesehatan Bhakti Husada: Health Sciences Journal, 10(1), pp.74-87.

Sari, N.I., Abidin, U.W. dan Ningsih, S., 2019. Faktor-Faktor yang Berhubungan dengan Minat Ibu dalam Pemilihan Alat Kontrsepsi IUD. Jurnal Kesehatan Masyarakat., 5(1), pp.47-59.

Siahaan, I.Y., Santosa, H. dan Sanusi, S.R., 2020. Relation of Reproductive and Economic Functions to the Selection of Long-Term Contraception in Women of Fertile Couples in Belukur Makmur Village, Rundeng Sub-District, 
Subulussalam City. Britain International of Exact Sciences (BIoEx) Journal, 2(1), pp.320-326.

SKAP, 2019. Survey Kinerja dan Akuntabilitas Program (SKAP) Keluarga 2019. Badan Kependudukan dan Keluarga Berencana Nasional . JakartaIndonesia.

Sumartini, S. dan Indriani, D., 2017. Pengaruh Keinginan Pasangan Usia Subur (PUS) dalam Penggunaan Metode Kontrasepsi Jangka Panjang. Jurnal Biometrika dan Kependudukan, 5(1), pp.27.

Syamsul, Bakri, B. dan Limonu, H.S., 2020. Penggunaan Alat KB pada Wanita Kawin di Perdesaan dan Perkotaan (Studi Hasil SDKI 2017 Provinsi Gorontalo). Jurnal Kependudukan Indonesia, 15(1), pp.71-84.

Wagner, K.P.G., Widman, L., Nesi, J. et al., 2018. Intentions To Use Emergency Contraception: The Role of Accurate Knowledge and Information Source Credibility. HHS Public Access, 49(4), pp. 264-270.

Yandrizal, Y., Suryani, D., Febriawati, H. dkk., 2016. Analisis Ketersediaan Fasilitas Kesehatan dan Pencapaian Universal Health Coverage Jaminan Kesehatan Nasional se Provinsi Bengkulu. Jurnal Kebijakan Kesehatan Indonesia, 5(3), pp.143-150.

Zuraidah, 2017. Pengaruh Pengetahuan terhadap Presepsi Istri dalam Penggunaan KB Non Hormonal. Jurnal Bidan "Midwife Journal," 3(01), pp.1-8. 